\title{
Chemical, mineralogical and structural features of native and expanded perlite from Macedonia
}

\author{
Arianit A. Rekaa, ${ }^{a}$, Blagoj Pavlovski ${ }^{\mathrm{b}}$, Kiril Lisichkov ${ }^{\mathrm{b}}$, Ahmed Jasharia ${ }^{\mathrm{a}}$, Blazo Boev ${ }^{\mathrm{c}}$, Ivan Boev, \\ Maja Lazarovac ${ }^{c}$, Volkan Eskizeybek ${ }^{\mathrm{d}}$, Ayhan Oral ${ }^{\mathrm{d}}$, Gligor Jovanovski ${ }^{\mathrm{e}}$ and Petre Makreski ${ }^{\mathrm{f}}$

\begin{abstract}
a University of Tetovo, Faculty of Natural Sciences and Mathematics, llinden n.n., 1200 Tetovo, Republic of Macedonia
b Ss. Cyril and Methodius University, Faculty of Technology and Metallurgy, Ruger Boskovic bb, 1000 Skopje, Republic of Macedonia

${ }^{c}$ Goce Delčev University, Faculty of Natural and Technical Sciences, Blvd. Krste Misirkov 10-A, 2000 Štip, Republic of Macedonia

d Çanakkale Onsekiz Mart University, Department of Materials Science and Engineering, Campus of Terzioglu 17100 Çanakkale, Turkey

e Macedonian Academy of Sciences and Arts, Research Center for Environment and Materials, Bul. Krste Misirkov 2, 1000, Skopje, Republic of Macedonia

${ }^{f}$ Institute of Chemistry, Faculty of Natural Sciences and Mathematics, Ss. Cyril and Methodius University, Arhimedova 5, 1000 Skopje, Republic of Macedonia; (*corresponding author: arianit.reka@unite.edu.mk)
\end{abstract}

doi: $10.4154 / g c .2019 .18$

Article history:

Manuscript received January 31, 2019

Revised manuscript accepted September 23, 2019

Available online October 31, 2019

\begin{abstract}
The physico-mechanical, chemical and mineralogical characteristics of volcanic glass (perlite) from the Mariovo region (Macedonia) as well as the mineralogical changes that occur during its thermal treatment were investigated to demonstrate its utilization for industrial use. The native perlite was characterized by chemical analysis, X-ray powder diffraction (XRPD), infrared (IR) spectroscopy, thermal analysis (TGA/DTA), scanning electron microscopy (SEM-EDX), transmission electron microscopy (TEM), and solid- state NMR. The chemical examination suggests that the perlite represents an acidic volcanic rock with a high percentage of $\mathrm{SiO}_{2}(72.45 \%)$, high in alkali metal oxides $\left(4.21 \mathrm{wt} . \% \mathrm{~K}_{2} \mathrm{O}, 3.56 \mathrm{wt} . \% \mathrm{Na}_{2} \mathrm{O}\right)$, with a loss of ignition $3.54 \mathrm{wt} . \%$. Results from the XRPD indicated major amorphous behaviour, with low amounts of feldspars, quartz, and cristobalite. SEM examinations revealed glassy structure with presence of certain pores (dimensions ranging from $50-100 \mu \mathrm{m}$ ). The determined expansion coefficient was 20 times its original volume. XRPD of expanded perlite compared to the native perlite depicted new intensive peaks of cristobalite. SEM and TEM revealed irregular morphology with broken or ragged edges. On the basis of the chemical and mineralogical composition, the studied perlite is classified as an appropriate material suitable as ceramic flux to lower the sintering temperature.
\end{abstract}

Keywords: perlite; volcanic rocks; chemical and mineralogical characterization; expansion coefficient comes pyroplastic and expands and increases 20 fold in volume. Bound water vaporizes and creates numerous bubbles that provide the exceptional characteristics of the perlite: a porous structure (increased porosity) and low weight (decreased density). Such material is known as expanded perlite; moreover, it expresses a low thermal conductivity, considerable heat resistance and acts as a very good sound absorber. The main components of perlite are the oxides such as $\mathrm{SiO}_{2}(70-75 \mathrm{wt} . \%), \mathrm{Al}_{2} \mathrm{O}_{3}(12-18$ wt.\%) as well as the alkaline oxides $\left(\mathrm{K}_{2} \mathrm{O}, \mathrm{Na}_{2} \mathrm{O}\right)$. Perlite also contains small amounts of other oxides such as $\mathrm{Fe}_{2} \mathrm{O}_{3}, \mathrm{CaO}, \mathrm{MgO}$ and $\mathrm{TiO}_{2}$ (ROULIA et al., 2006; BURRIESCI et al., 1985; KAUFHOLD et al., 2014; VARGA et al., 2015).

Perlites, either as native materials or expanded, due to their properties (low density, high porosity, chemical inertness and non-toxicity), are versatile materials and used for the preparation of catalysts, ceiling tiles, pipe insulation, gypsum wallboard, cryogenic insulation, fillers, materials for filtering (filters), aggregates for light cement, removal of heavy metals and adsorption of particulates from the atmosphere, thermal insulators, absorption of oil, roof panels, foams, fire retardants, brick products, horticulture, production of container glass, in the ceramic industry (as a component in the ceramic mass), microorganism carriers, materials for improving the mechanical and thermal properties of cement mortar, and glaze products (AHMADIA et al, 2018; SODEYAMA etal., 1999; ZAFIROVSKIetal., 1987; VIJAYARAGHAVAN and RAJA, 2014; RODRIGUEZ et al., 2016). The application of 
perlite for these purposes depends on the physico-chemical characteristics, as well as from its mineralogical composition.

Perlite mines are located in several countries around the world, with the leading producers being Turkey, Greece, USA, Japan, Italy and Hungary (SODEYAMA et al., 1999; SODEYAMA and SAKKA, 2005). It is estimated that the Republic of Macedonia contains over 1.18 million tons of perlite (SPASOVSKI and SPASOVSKI, 2012), found in the Tertiary volcanics. The major area is at Nidze Mountain, close to the border with Greece, where perlite is associated with Pliocene latite in the Gradesnica deposit (KOGEL et al., 2006). Preparation for excavation was planned in the late 1990s with production expected to reach 80 ktpy (HARBEN and KUZVART, 1997), but no actual extraction occurred.

The aim of this study was to determine, for the first time, the physico-mechanical, chemical and mineralogical characteristics of perlite from the Mariovo region, and to investigate the mineralogical changes that occur during thermal treatment. Therefore, our goal was to resolve the most appropriate valorization of this volcanic rock from this locality as well as to determine its expansion coefficient.

\section{MATERIALS AND METHODS}

The perlite was collected from the Mariovo region (Fig. 1). The samples were fine-grained of a white to greyish colour, with white phenocrysts, and granulation of $0.2-0.5 \mathrm{~mm}$ was used for the measurements. The specific gravity of the natural perlite was determined by pycnometer (as per the standard D 854 - 02 - Standard Test Methods for Specific Gravity of Soil Solids by Water Pycnometer1), while the compressive strength was determined with an automatic press (Automax 5, Controls).

The chemical composition of the volcanic glass was determined using classical silicate analysis. Crude perlite was melted in a mixture of carbonates $\left(\mathrm{Na}_{2} \mathrm{CO}_{3}\right.$ and $\left.\mathrm{K}_{2} \mathrm{CO}_{3}\right)$, whereas the percentages of the various oxides present in the material were determined by complexometric titration (KIRSCHENBAUM, 1983). The alkali metal oxides $\left(\mathrm{Na}_{2} \mathrm{O}\right.$ and $\left.\mathrm{K}_{2} \mathrm{O}\right)$ were determined by flame photometry using an Evans Electroselenium Ltd 410 instrument.

The mineralogical characterization was carried out using X-ray powder diffraction (XRPD), thermal analysis (TGA/DTA), scanning electron microscopy (SEM-EDX), transmission electron microscopy (TEM) and infrared spectroscopy (IR). XRPD analysis was performed on a Rigaku Ultima IV X-ray diffractometer equipped with a D/teX high-speed 1-dimenzional detector using $\mathrm{Cu} K \alpha$ radiation $(\lambda=1.54178 \AA)$ in $2 \theta$ range from 5 to $60^{\circ}$. The accelerating voltage and the current power were set to $40 \mathrm{kV}$ and $40 \mathrm{~mA}$, respectively.

DTA/TGA analyses of the volcanic glass were performed using a Stanton Redcroft apparatus, under the following experimental conditions: temperature range $20-1000{ }^{\circ} \mathrm{C}$; heating rate $10^{\circ} \mathrm{C} / \mathrm{min}$ and a thermal treatment duration time of $98 \mathrm{~min}$; sample mass of $19.085 \mathrm{mg}$, with a ceramic pot as a material carrier. The optical microscopy measurements were conducted on a transmission polarizing microscope SM-POL, Leitz, Wetzlar, Germany.

A scanning electron microscope VEGA3 LMU Tescan Instrument coupled with energy dispersive X-ray spectroscopy (INCA Energy 250 Microanalysis System) was used to quantitatively analyze the products. The voltage of the SE detector was set to $20 \mathrm{kV}$. A JEOL 2100 transmission electron microscope (TEM) was used to obtain TEM photographs of the volcanic glass. The Perkin-Elmer FTIR system 2000 interferometer was engaged to record the IR spectra in $4000-500 \mathrm{~cm}^{-1}$ range using the KBr pellet method. Solid state NMR characterizations of volcanic glass were carried out using a Jeol $400 \mathrm{MHz}$ nuclear resonance spectrophotometer.

In order to determine the expansion coefficient of this volcanic glass, crude perlite was initially dried at $100{ }^{\circ} \mathrm{C}$ and subsequently subjected to thermal treatment at $850{ }^{\circ} \mathrm{C}$ at which the water trapped in the structure vaporized and escaped resulting in the expansion of the material. The expansion coefficient of perlite is equal to 20 times its initial volume (Fig. 2, right). The bulk density of $62 \mathrm{~g} / \mathrm{dm}^{3}\left(0.062 \mathrm{~g} / \mathrm{cm}^{3}\right)$ was determined for the expanded perlite.

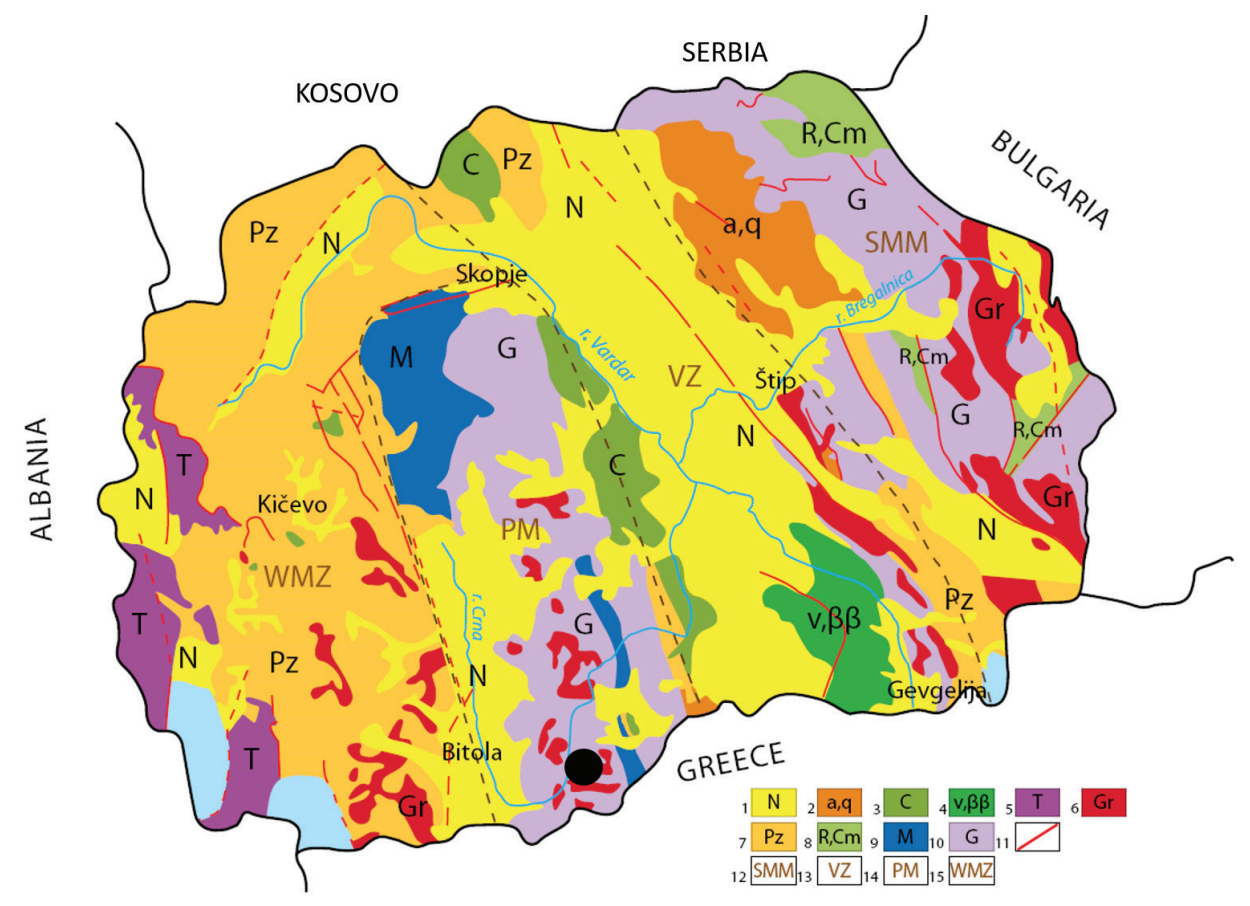

Figure 1. A geological map of Macedonia pinpointing the locality (black circle) from where the perlite was excavated. 

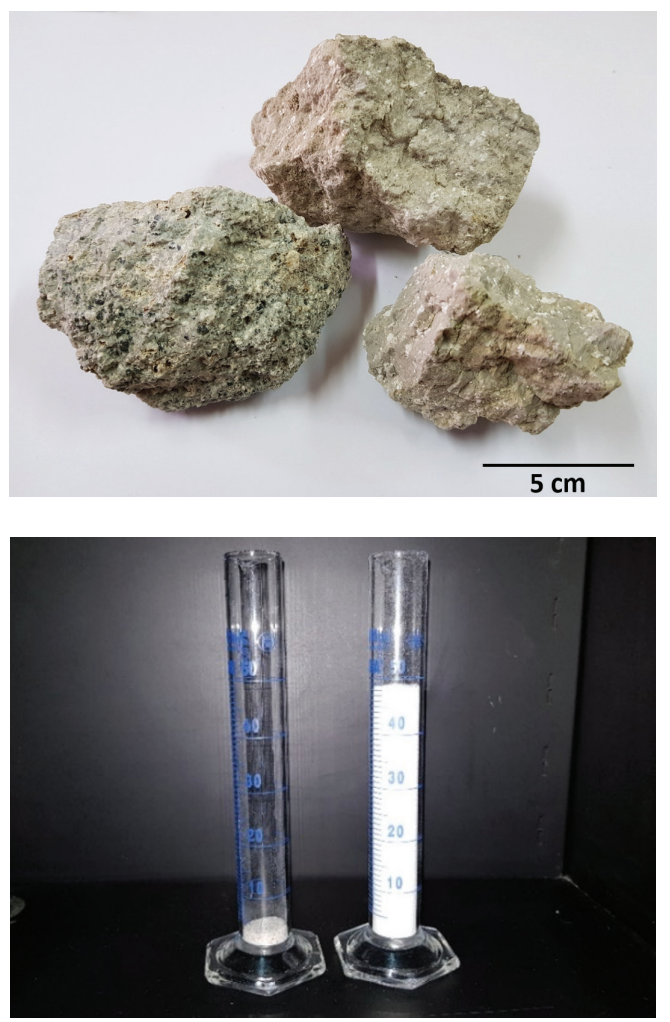

Figure 2. Natural (crude) perlite from Mariovo region (up). Comparison of the volume of the same mass $(3.1 \mathrm{~g})$ of perlite and expanded perlite (down). The volume of $2.5 \mathrm{ml}$ of native perlite versus the volume of $50 \mathrm{ml}$ of the expanded perlite.

\section{RESULTS AND DISCUSSION}

\subsection{Physico-mechanical properties of perlite}

The perlite was excavated from the Mariovo region (Fig. 1). The following physico-mechanical properties were determined for the native perlite (Fig. 2, left): white to light grey colour, odourless, with clearly visible black particles of glass. The specific gravity of the natural perlite was determined by pycnometer (Standard D 854 - 02 - Standard Test Methods for Specific Gravity of Soil Solids by Water Pycnometer) as $2.23-2.40 \mathrm{~g} / \mathrm{cm}^{3}$, while the compressive strength was in the range from 4.20 to $5.30 \mathrm{MPa}$.

The process of expanding the natural perlite was monitored by expansion in industrial vertical expansion furnaces. In order to obtain the maximum expansion at this grain size $(0.2-0.5 \mathrm{~mm})$, perlite was preheated at $350-400{ }^{\circ} \mathrm{C}$ for a period of $4-5$ seconds and afterwards heated at $850{ }^{\circ} \mathrm{C}$ in the high temperature furnace for 2-3 seconds.

\subsection{Chemical analysis of perlite}

The chemical composition of the volcanic rock (Table 1) was determined with the classical chemical silicate analysis. The loss of ignition (LOI) was determined while heating perlite at $1000{ }^{\circ} \mathrm{C}$ for a period of 1 hour; LOI was 3.54\% and lies within the typical range for perlites $(3-5 \%)$.

The results obtained from the chemical composition of perlite indicate that the analyzed perlite represents an acidic volcanic rock with a high percentage of $\mathrm{SiO}_{2}(72.48 \%)$ and substantial amounts of $\mathrm{Al}_{2} \mathrm{O}_{3}(13.15 \%)$. The alkali metal oxides $\left(\mathrm{K}_{2} \mathrm{O}\right.$ and $\mathrm{Na}_{2} \mathrm{O}$ ) are present at $4.21 \%$ and $3.56 \%$ respectively, (representing high percentages) indicates that the analyzed raw material is suitable for container glass.
Table 1. Chemical composition of perlite.

\begin{tabular}{cc}
\hline Oxides & Mass \% \\
\hline $\mathrm{SiO}_{2}$ & 72.48 \\
$\mathrm{Al}_{2} \mathrm{O}_{3}$ & 13.15 \\
$\mathrm{Fe}_{2} \mathrm{O}_{3}$ & 1.23 \\
$\mathrm{TiO}_{2}$ & 0.15 \\
$\mathrm{CaO}$ & 1.13 \\
$\mathrm{MgO}$ & 0.35 \\
$\mathrm{~K}_{2} \mathrm{O}$ & 4.21 \\
$\mathrm{Na}_{2} \mathrm{O}$ & 3.56 \\
$\mathrm{LOI}$ & 3.54 \\
$\mathrm{Total}$ & 99.80 \\
\hline
\end{tabular}

\subsection{X-ray powder diffraction analysis of the native and expanded perlite}

Results of the XRPD analysis of the perlite (Fig. 3, top) depicts the amorphous behaviour of the sample manifested by the appearance of one complex "hump" widely positioned between 15 and $30^{\circ}(2 \theta)$ with the most maxima peaking in the $22-26.7^{\circ}$ range as a result of the high percentage of the aluminosilicate glass phase associated by small amounts of crystalline phases. The small quantities of the crystalline phases are mainly represented by feldspars, quartz and cristobalite. Feldspars are represented as plagioclases $\left(13.50^{\circ}, 25.76^{\circ}, 29.98^{\circ}, 33.64^{\circ}, 35.40^{\circ}, 42.66^{\circ}, 49.74^{\circ}\right)$, $\mathrm{K}$, Na-feldspars $\left(23.70^{\circ}, 27.40^{\circ}, 27.66^{\circ}\right)$, and microcline $(27.66$, $29.49,50.58)$. The less pronounced presence of $\mathrm{SiO}_{2}$ polymorphs

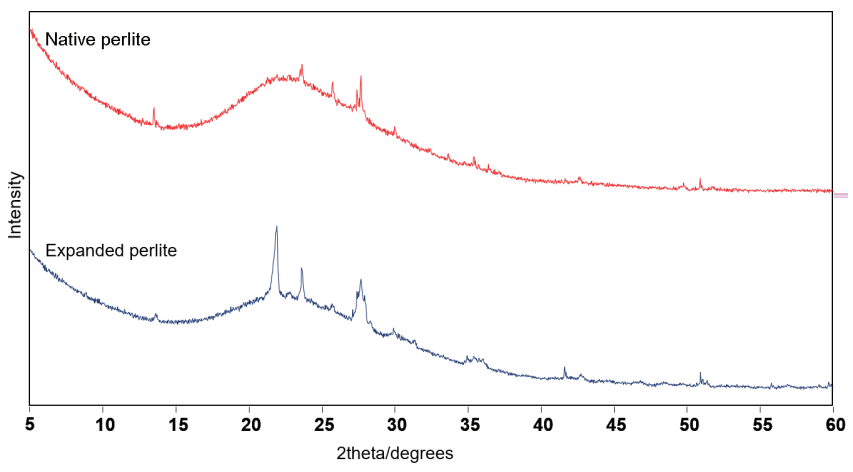

Figure 3. XRPD analysis of native perlite (top) and expanded perlite (bottom).

are represented by $\alpha$-quartz $\left(26.67^{\circ}\right)$ and cristobalite $\left(21.94^{\circ}\right)$. The presence of crystalline modifications in the volcanic rock is correlated to the origin of perlite, with more crystallites being formed in the slow cooling of the lava.

Results of the XRPD analysis of the expended perlite (Fig. 3 , bottom) again demonstrated the amorphous behaviour of the sample manifested by the appearance of one complex "hump" extended between 15 and $30^{\circ}(2 \theta)$ with the most maxima peaking in the $22-26.7^{\circ}$ range as a result from the high percentage of aluminosilicate glass. Compared to the native perlite, the expanded perlite shows an evident increase in the amount of cristobalite $\left(21.94^{\circ}, 28.44,31.40,36.00\right)$ present.

\subsection{Infrared spectral analysis of the native and the expanded perlite}

The IR spectrum of native perlite (Fig. 4, top) exhibits an absorption band at $786 \mathrm{~cm}^{-1}$ attributed to the bending vibrations of the $\mathrm{Si}-\mathrm{O}-\mathrm{Si}$ framework, whereas the band at $1078 \mathrm{~cm}^{-1}$ is a result of 


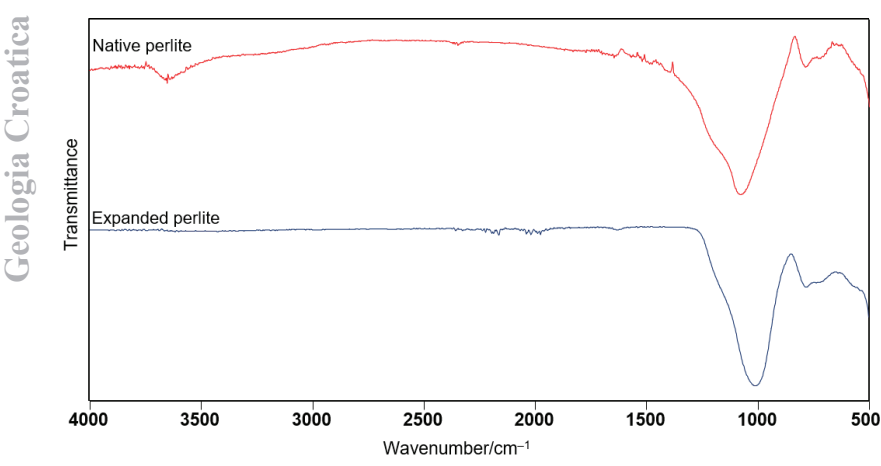

Figure 4. IR spectrum of native perlite (top) and expanded perlite (bottom).

the stretching vibrations of the Si-O-Al units (SODEYAMA et al., 1999; MAKRESKI et al., 2009). The band at $1644 \mathrm{~cm}^{-1}$ is due to bending vibrations from the absorbed water (ROULIA et al., 2006; VARUZHANYAN et al., 2006; MAKRESKI et al., 2009), whereas the band at $3650 \mathrm{~cm}^{-1}$ is due to the stretching vibration of the absorbed water molecules (SODEYAMA et al., 1999; LI and TOMOZAWA, 1994).

As results of the thermal treatment and water loss during the expansion of perlite, the bands at $1644 \mathrm{~cm}^{-1}$ and $3650 \mathrm{~cm}^{-1}$ that were previously discussed at the native perlite (Fig. 4, bottom), bands due to bending vibrations from the absorbed water and the stretching vibration of the absorbed water molecules (ROULIA et al., 2006; VARUZHANYAN et al., 2006; MAKRESKI et al., 2009), as expected, are missing in the IR spectrum of the expanded perlite (Fig. 4, bottom). The band at $785 \mathrm{~cm}^{-1}$ and 1047 $\mathrm{cm}^{-1}$ are ascribed to the $\mathrm{Si}-\mathrm{O}$ stretching vibrations of $\mathrm{Si}-\mathrm{O}-\mathrm{Si}$ and Si-O-Al, respectively (SODEYAMA et al., 1999).

\subsection{Optical microscopy}

The results of the light microscopy demonstrated the sample composition of an isotropic glassy mass (Fig. 5) with the presence of glassy-isotropic fine-grained particles/microlites $(0.03-0.1 \mathrm{~mm})$. In the fine-grained mass of the raw material, besides the microlites, phenocrysts of quartz with dimensions varying from 2 to $3 \mathrm{~mm}$ are observed, corroded in the mass itself (Fig. 5).
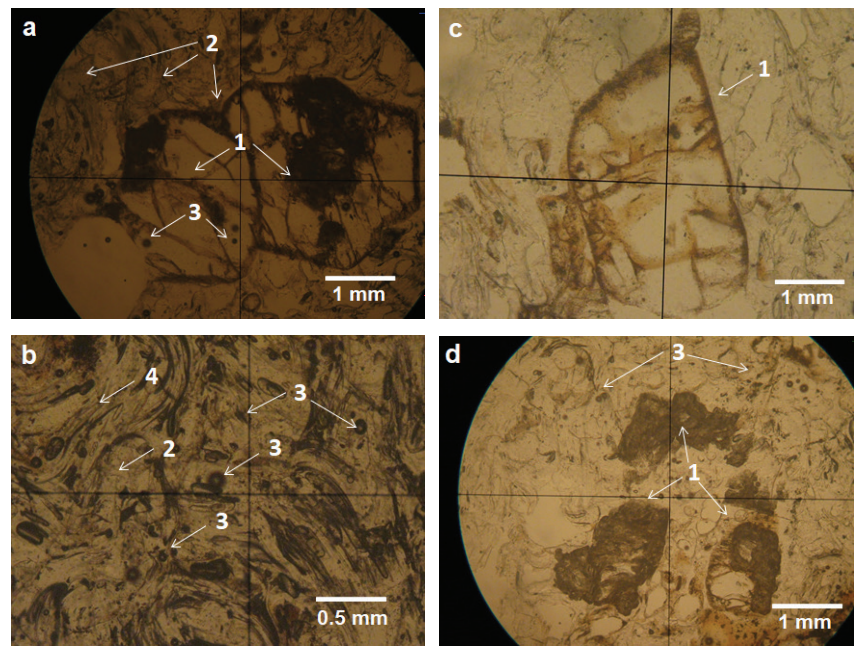

Figure 5. Optical photomicrographs of perlite: a) 2-3 mm quartz phenocryst (1) and microlite (3) embedded in the glassy mass (2) with indications of corrosion of the crystal; b) isotropic microlites (3) with prevalence of turbulent, fluidal movement (4) of the glassy phase (2); c) corroded phenocryst (1) from the glassy mass; d) microlite (3) and corroded phenocrysts (1) of pigmented isotropic minerals (most likely carriers of $\mathrm{Fe}$, $\mathrm{Ti}$ and $\mathrm{Mn}$ ) from the glassy mass.
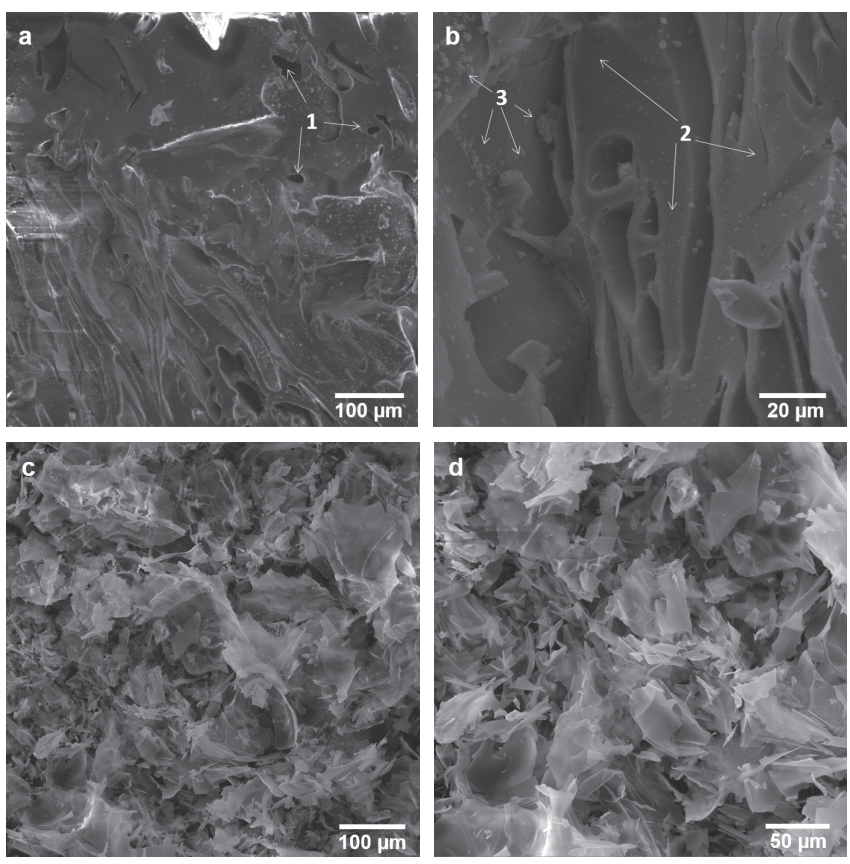

Figure 6. SEM photomicrographs of crude perlite $(a, b)$ and the expanded perlite $(c, d)$. Perlite shows open pores (1), glassy mass (2), and tiny crystals (3).

\subsection{Scanning electron microscopy (SEM-EDX) and transmission electron microscopy (TEM) of the native and expanded perlite}

The results from the SEM of crude perlite (Figs. 6a,b) confirm the findings from the optical microscopy. The evidence of open pores and the fluid character of the glassy phase are depicted in Fig. 6a, whereas Fig. 6b illustrates compact glass mass of the perlite with presence of the tiny crystals.

Scanning electron microscopy (SEM) was also employed to study the induced material alteration by the expansion process (Fig. 6c, d). During the heat treatment, the grains start to soften superficially and the outer shell becomes smooth, while the water trapped in the thin layers escaped resulting in expansion of the grain. The grains explode vigorously with considerable morphological alteration (ROULIA et al., 2006).

The expanded perlite particles exhibited irregular morphology with broken or ragged edges. The perlite particles exhibit some internal cellular structure. The microstructure of the expanded perlite is characterized by vast open pores (small channels which form a dense network) and some isolated holes and cells.

According to the area spectrum of EDX analysis, the presence of $\mathrm{O}, \mathrm{Na}, \mathrm{Al}, \mathrm{Si}$ and $\mathrm{K}$ elements in the structure of the native perlite was quantitatively determined (Fig. 7). Namely, the chemical composition and weight percentage of the elements in perlite (O: $51.40 \%$, Na: $2.00 \%$, Al: $6.72 \%$, Si: $35.03 \%$, and K: $4.84 \%$ ) correspond to the prevailing glassy phase in perlite (Fig. 7a, c). On the other hand, the chemical composition obtained from carefully selected spheres with dimensions smaller than 1-5 $\mu \mathrm{m}(\mathrm{O}$ : 63.19\%, Al: $7.04 \%$, and $\mathrm{Si}: 29.76 \%$ ) served as evidence for the presence of crystalline aluminosilicates in perlite (Fig. 7b, d).

The results from the transmission electron microscopy of the crude perlite show that the main mass of perlite is volcanic glass (Fig. 8). TEM also shows that the glassy mass of native perlite nests presence of very fine crystalline phases, with dimensions ranging from $10-50 \mathrm{~nm}$ (Fig. 8). These results correspond to 


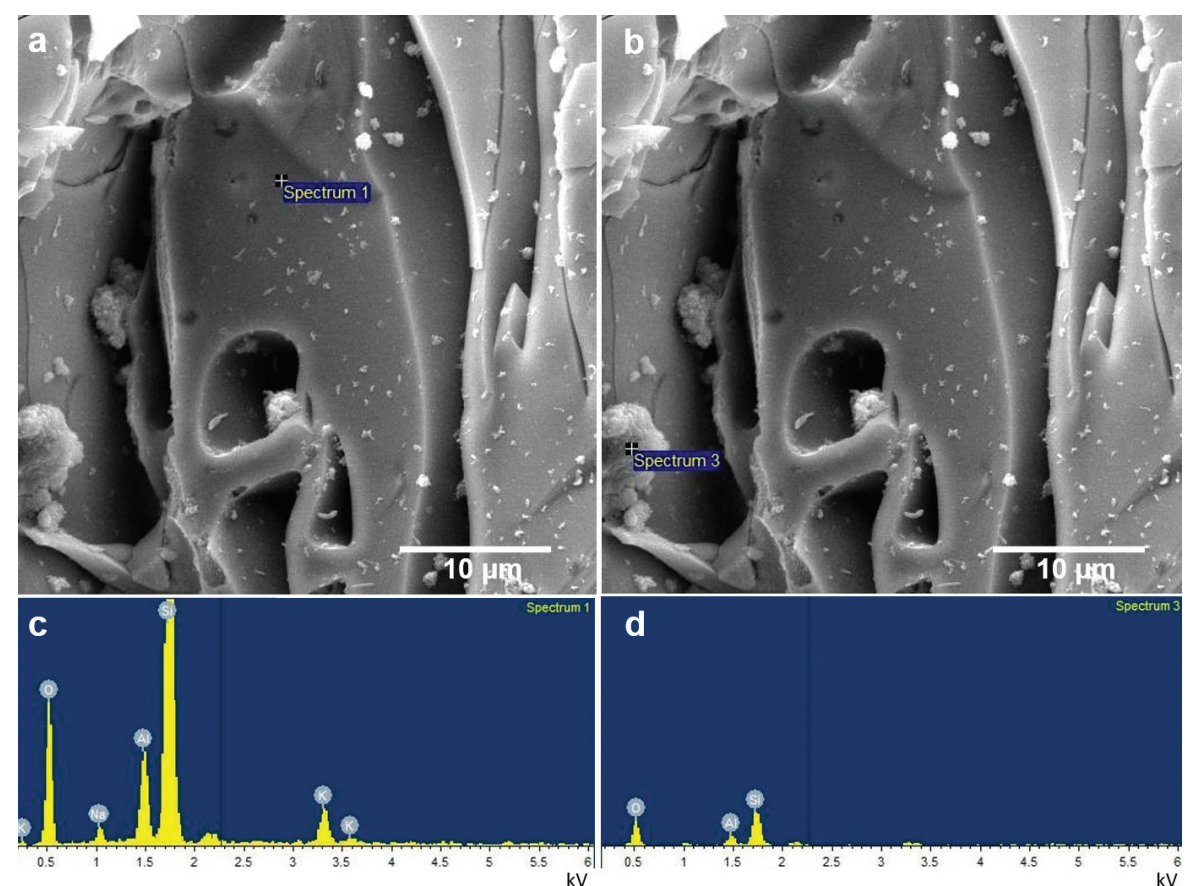

Figure 7. SEM photomicrographs of native perlite: the glassy/amorphous (a) and crystalline phase (b) and the corresponding element content as determined by $\operatorname{EDS}(c, d)$.
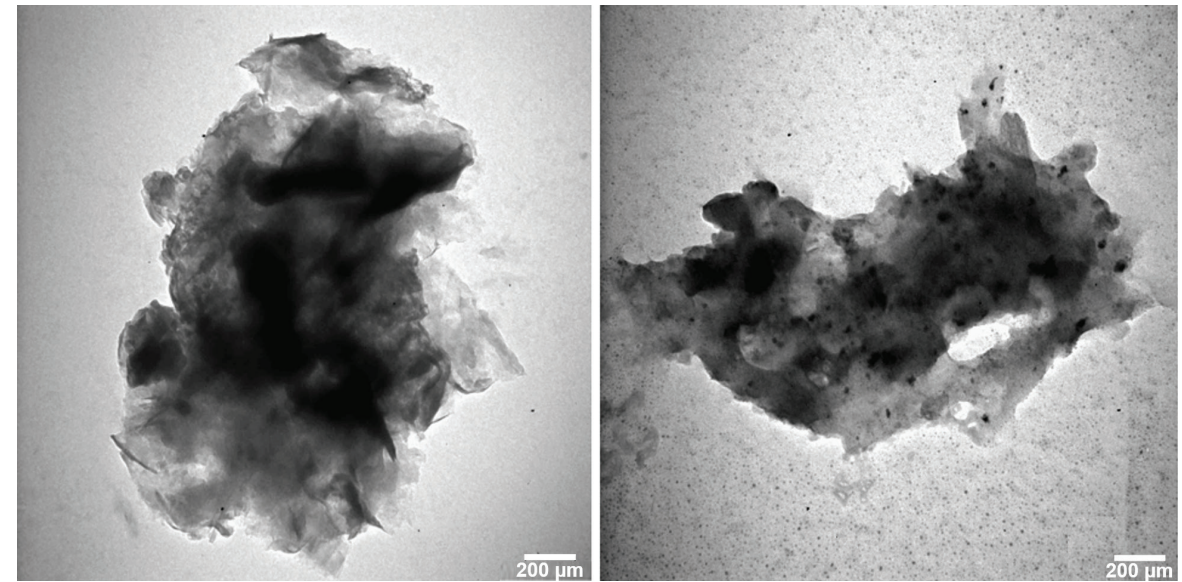

Figure 8. TEM photomicrographs of the glassy mass in perlite (left) and the crystalline phases in the volcanic glass (right).

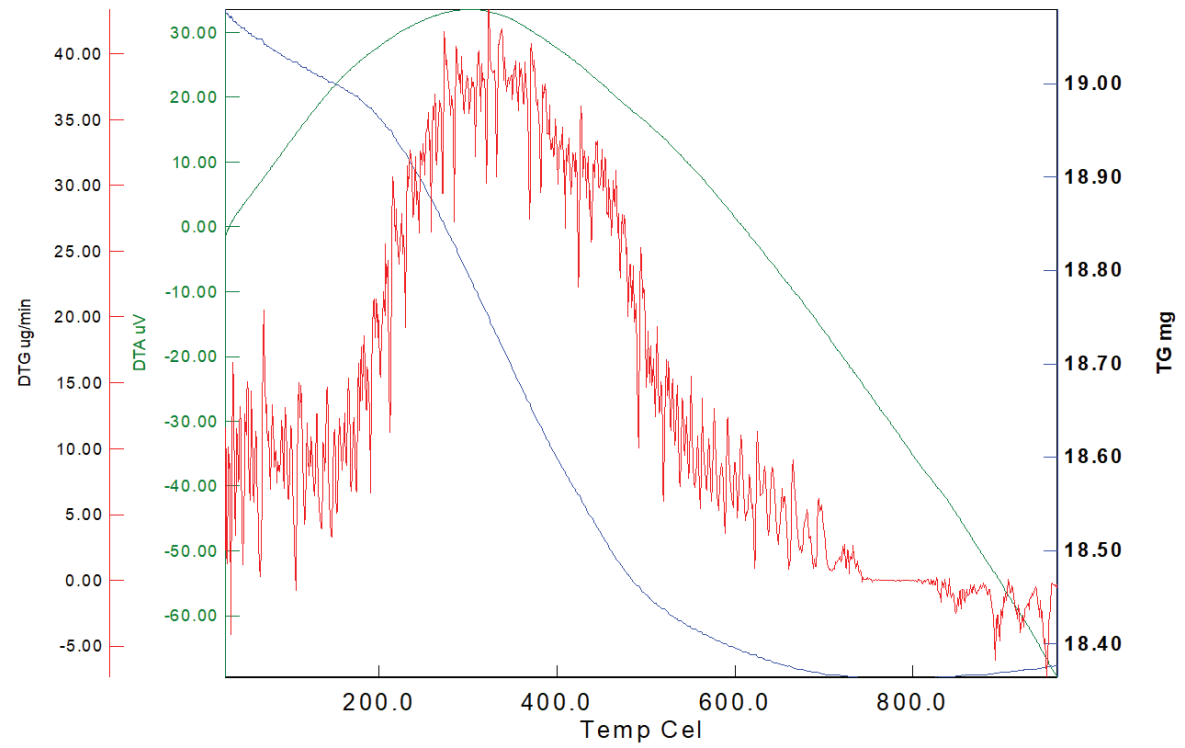

Figure 9. The DTA/TGA curves of native perlite. 


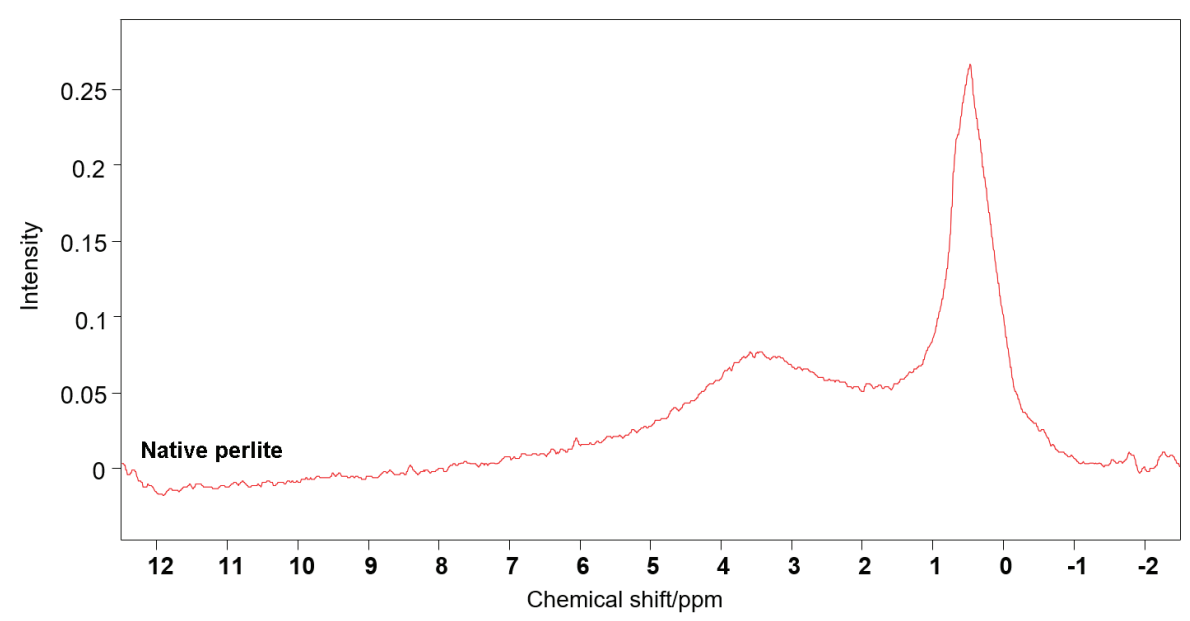

Figure 10. Solid state 1H NMR spectrum of the native perlite (volcanic glass).

XRPD observations where the amorphous phase prevailed and a relatively low crystalline phase (tiny crystals) was observed. These results are also complementary with the composition of volcanic glass observed by EDX measurement.

\subsection{Thermal examinations}

The thermogravimetric analysis (TGA) and the differential thermal analysis (DTA) of the analyzed raw volcanic rock indicates weight loss in three temperature intervals (Fig. 9). The first temperature interval is between 20 and $215^{\circ} \mathrm{C}$ resulting with a subtle weight loss of $0.68 \%$ attributed to the loss of adsorbed water on the perlite surface. The major mass loss of $2.69 \%$ occurs in the temperature interval from $215-477^{\circ} \mathrm{C}$ and is a consequence of the hydroxyl groups release. Bearing in mind the absence of organic matter due to the lack of determined carbon (according to the chemical analysis), we suggest that the remaining chemically bonded water (0.43\%) (ROULIA et al., 2006; CELIK et al., 2013), is released in the temperature interval from $477-826^{\circ} \mathrm{C}$.

\subsection{Solid state (CP-MAS) ${ }^{1} \mathrm{H}$ NMR spectroscopy}

The ${ }^{1} \mathrm{H}$ CP-MAS NMR spectra of the crude perlite (Fig. 10) consists of two peaks. The first maximum around $0.3 \mathrm{ppm}$ is very intensive and relatively narrow, whereas the second weak and broad peak evolves around $3.5 \mathrm{ppm}$. This second peak exhibits a broad appearance due to the overlapping of the signals from the homonuclear dipolar interactions and chemical shift distribution caused by sample disorder, reflecting the predominant amorphous nature of the analyzed specimen.

The obtained spectrum compares well with previous published solid state ${ }^{1} \mathrm{H}$ NMR spectra of perlite from other regions (ZUJOVIC et al., 2018). However, the lower or more narrow but intensive signal at $0.3 \mathrm{ppm}$ serves as an indicator for the crystallinity phase of the sample that was also depicted from the collected XRPD spectrum (see Fig. 3, top).

\section{CONCLUSIONS}

The first full characterization of the unexpanded and expanded perlite from Mariovo allows the following conclusions to be drawn:

i) Chemical analysis of the volcanic rock suggests that the raw material represents acidic volcanic rock, with a high percentage of $\mathrm{SiO}_{2}(72.48 \%)$, whereas the presence of $\mathrm{Al}_{2} \mathrm{O}_{3}$ is $13.52 \%$. The percentage of alkali metal oxides, $\mathrm{K}_{2} \mathrm{O}$ and $\mathrm{Na}_{2} \mathrm{O}$ is $4.21 \%$ and $3.56 \%$ respectively. ii) Results from the XRD examination suggest a high percentage of amorphous phase, with the minimal presence of crystalline forms. The crystalline phase is mainly composed of feldspars, and $\mathrm{SiO}_{2}$ polymorphs (quartz and cristobalite).

iii) The results from the optical microscopy confirm the results from the XRD analysis; the volcanic rock is composed of an isotropic amorphous glassy mass with the presence of finegrained particles-microlite.

iv) The SEM results are commensurate with the findings delivered by optical microscopy. SEM photomicrographs undoubtedly report on the fluid character of the glassy mass and the compact glass mass of the perlite with the presence of tiny crystals and pores. On the other hand, the SEM results from the expanded perlite revealed the presence of open pores (small channels which form a dense network) and some isolated holes and cells in its microstructure. The simultaneous presence of these open pores and isolated holes delivers extremely high transpiring power (absorb water and then release the water in the form of vapour) and high strength, respectively. The difference is pronounced by the fact that the transpiring characteristic plays a pivotal role in the thermal insulation property of the material, whereas high strength is needed for structural lightweight concrete.

v) Total mass loss of $3.80 \mathrm{wt} . \%$ observed during the TG treatment was correlated with trapped water escaping from the volcanic rock.

vi) The IR spectrum provides valuable information regarding the presence of absorbed water in perlite $\left(1644 \mathrm{~cm}^{-1}\right.$ and 3650 $\mathrm{cm}^{-1}$ bands) that was essentially excreted during the expansion process (the corresponding bands disappeared).

Due to the low proportion of a crystalline phase fortified by the abovementioned results, it can be concluded that analyzed volcanic rock (perlite), represents valuable starting material for production of high quality expanded perlite. As a result of the high percentage of alkali metal oxides, the high percentage of $\mathrm{SiO}_{2}$, the volcanic glass (perlite) can be utilized as a raw material for the production of container glass. The high percentage of the glassy phase, high percentage of $\mathrm{SiO}_{2}$ and alkali metal oxides makes perlite from Mariovo an attractive material for the production of acid resistant glazing materials.

\section{REFERENCES}

AHMADIA, P.F., ARDESHIRA, A., RAMEZANIANPOURB, A.M. \& BAYATA, H. (2018): Characteristics of heat insulating clay bricks made from zeolite, waste steel slag and expanded perlite.- Ceram. Int., 44, 7588-7598. doi: 10.1016/j.ceramint.2018.01.175 
BREESE, R.O.Y. (1984): Rhyolite domes and flows at No Aqua Peaks.- Proceeding of the 35th Annual Field Conference, Socorro, New Mexico Geological Society, 373-374.

BURRIESCI, N., ARCORACI, C., ANTONUCCI, PL. \& POLIZZOTTI, G. (1985): Physico-chemical characterization of perlite of various origins.- Mater. Lett., 3, 103-110. doi: 10.1016/0167-577X(85)90008-4

CEKOVA, B., PAVLOVSKI, B., SPASEV, D. \& REKA, A. (2013): Structural examinations of natural raw materials pumice and trepel from Republic of Macedonia.Proceedings of the XV Balkan Mineral Processing Congress, Sozopol, Bulgaria, $73-75$.

CELIK, A.G., KILIC, A.M. \& CAKAL, G.O. (2013): Expanded perlite aggregate characterization for use as a lightweight construction raw material.- Physicochem. Probl. Miner. Process., 49, 689-700. doi: 10.5277/ppmp130227

EVANS, A.M. (1993): Perlite.- Ore Geology and Industrial Minerals, 3rd Edition, Oxford, Boston, Blackwell Science, 295-296.

HARBEN, P.W. \& KUZVART, M. (1997): Industrial Minerals - A global geology.- Industrial Minerals Information, London, Metals Bulletin, 280-288.

JOVANOVSKI, G., BOEV, B. \& MAKRESKI, P. (2012): Minerals from the Republic of Macedonia with an Introduction to Mineralogy, Macedonian Academy of Sciences and Arts, Skopje, 1-652.

KAUFHOLD, S., REESE, A., SCHWIEBACHER, W., DOHRMANN, R., GRATHOFF, G.H., WARR, L.N., HALISCH, M., MÜLLER, C., SCHWARZ-SCHAMPERA, U. \& UFER., K. (2014): Porosity and distribution of water in perlite from the island of Milos, Greece.- SpringerPlus 3, 598 (pages 10). doi: 10.1186/2193-18013-598

KIRSCHENBAUM, H. (1983): The classical chemical analysis of silicate rocks - the old and the new.- Geol. Survey Bull., 1547, 1-55. doi: 10.3133/b1547

KOGEL, J.E., TRIVEDI, N.C., BAKER, J.M. \& KURKOWSKI, S.T. (2006): Industrial Minerals \& Rocks, 7th Edition. Society for Mining, Metallurgy and Exploration, Inc., 865 p.

KONGKACHUICHAY, P. \& LOHSOONTORN, P. (2006): Phase diagram of zeolite synthesized from perlite and rice husk ash.-ScienceAsia, 32, 13-16. doi: 10.2306/ scienceasia1513-1874.2006.32.013

KOUKOUZAS, N. (1998): Volcanic glass (perlite) of Kimolos Island, Greece: Mineral chemistry and structure.- Proceedings of the 8th International, Patras, Bulletin of the Geological Society of Greece, XXXII/3, 313-332.

LI, H. \& TOMOZAWA, M. (1994): Mechanical strength increase of abraded silica glass by high pressure water vapor treatment.- J. Non-Cryst. Solids, 168, 287-292. doi: 10.1016/0022-3093(94)90341-7

MAKRESKI, P. \& JOVANOVSKI, G. (2003): Minerals from Macedonia. IX. Distinction between some rhombohedral carbonates by FTIR spectroscopy. - Bull. Chem. Technol. Macedonia, 22, 25-32.

MAKRESKI, P., JOVANOVSKI, G. \& KAITNER, B. (2009): Minerals from Macedonia. XXIV. Spectra-structure characterization of tectosilicates.- J. Mol. Struct., 924-926, 413-419. doi: 10.1016/j.molstruc.2009.01.001
PAVlOVSKI, B., JANČEV, S., PETRESKI, L., REKA, A., BOGOEVSKI, S. \& BOŠKOVSKI, B. (2011): Trepel - a peculiar sedimentary rock of biogenetic origin from the Suvodol village, Bitola, R. Macedonia.- Geologica Macedonica, 25, $67-72$.

REKA, A.A., ANOVSKI, T., BOGOEVSKI, S., PAVLOVSKI, B. \& BOŠKOVSKI, B. (2014): Physical-chemical and mineralogical-petrographic examinations of diatomite from deposit near village of Rožden, Republic of Macedonia.- Geologica Macedonica, 28, 121-126.

REKA, A.A., PAVLOVSKI, B. \& MAKRESKI, P. (2017): New optimized method for low-temperature hydrothermal production of porous ceramics using diatomaceous earth.- Ceram. Int., 43, 12572-12578. doi: 10.1016/j.ceramint.2017.06.132

RODRIGUEZ, J., SORIA, F., GERONAZZO, H. \& DESTEFANIS, H. (2016): Modification and characterization of natural aluminosilicates, expanded perlite, and its application to immobilise $\alpha$-amylase from A. oryzae.- J. Mol. Catal. B, 133, S259S270. doi: 10.1016/j.molcatb.2017.01.012

ROULIA, M., CHASSAPIS, K., KAPOUTSIS, J.A., KAMITSOS, E.I. \& SAVVIDIS, T. (2006): Influence of thermal treatment on the water release and the glassy structure of perlite.- J. Mater. Sci., 41, 5870-5881. doi: 10.1007/s10853-006-0325-z

SODEYAMA, K. \& SAKKA, Y. (2007): Preparation and utilization of fine expanded perlite.- Key. Eng. Mat., 280-283, 701-706. doi: 10.4028/www.scientific.net/ KEM.280-283.701

SODEYAMA, K., SAKKA, Y., KAMINO, Y. \& SEKI, H. (1999): Preparation of fine expanded perlite.- J. Mater. Sci., 34, 2461-2468.

ŠONTEVSKA, V., JOVANOVSKI, G. \& MAKRESKI, P. (2007): Minerals from Macedonia. Part XIX. Vibrational spectra of some sheet silicate minerals.- J. Mol. Struct., 834-836, 318-327. doi: 10.1016/j.molstruc.2006.10.026

SPASOVSKI, O. \& SPASOVSKI, D. (2012): The potential of the nonmetallic mineral resources in the Republic of Macedonia.- Geologica Macedonica, 26, 91-94.

VARGA, P., LEXA, J., UHLÍK, P. \& RAJNOHA, M. (2015): Characterization of perlites from Jastrabá and Lehôtka pod Brehmi deposits.- Geol. Geophys. Environ., 41, 146-146. doi: 10.7494/geol.2015.41.1.146

VARUZHANYAN, AV.A., VARUZHANYAN, AR.A. \& VARUZHANYAN, H.A. (2006): A mechanism of perlite expansion.- Inorg. Mater., 42, 1039-1045. doi: 10.1134/S0020168506090202

VIJAYARAGHAVAN, K. \& RAJA, F.D. (2014): Experimental characterisation and evaluation of perlite as a sorbent for heavy metal ions in single and quaternary solutions.- J. Water Process Eng., 4, 179-184. doi: 10.1016/j.jwpe.2014.10.001

ZAFIROVSKI, S., JASMAKOVSKI, B., ZLATANOVIC, V. \& PAVLOVSKI, B. (1987): Use of perlites in the ceramic industry.-2nd Int. Conf. of Natural Glasses, Prague, $169-175$.

ZUJOVIC, Z., WHEELWRIGHT, W.V.K, KILMARTINA, P.A., HANNA, J.V. \& COONEY, R.P. (2018): Structural investigations of perlite and expanded perlite using ${ }^{1} \mathrm{H},{ }^{27} \mathrm{Al}$ and ${ }^{29} \mathrm{Si}$ solid-state NMR.- Ceram. Int., 44, 2952-2958. doi: 10.1016/j.ceramint.2017.11.047 